\title{
РЕСУРСНЫЙ ПОТЕНЦИАЛ КАК ФАКТОР ЭКОНОМИЧЕСКОГО РОСТА СИБИРСКИХ РЕГИОНОВ
}

\author{
В.И. Татаренко, Р.Д. Камалов \\ Новосибирский государственный университет экономики и управления (Новосибирск, Россия)
}

Ресурсная база Сибири - один из основополагающих элементов конкурентноспособности экономики России. Правильное и рациональное использование имеющихся ресурсов способно трансформировать «сырьевое проклятие» в драйвер значительного экономического и промышленного роста как региональных экономик, так и государства. России принадлежит более $30 \%$ всех природных ресурсов в мире. Огромные топливно-энергетические ресурсы открыты почти во всех экономических районах РФ, но главная, базовая их часть сосредоточена в Сибири. Между тем современный этап в экономическом развитии Сибирских регионов обусловлен внешнеэкономическим фактором - «азиатским» вектором экономического сотрудничества. Российско-китайское сотрудничество способно придать новый импульс социальноэкономическому развитию сибирских регионов.

Ключевые слова: Сибирь, промышленные ресурсы, рост экономики, рациональность, недропользование, инновации, Газпром, Сила Сибири, Китай.

\section{RESOURCE POTENTIAL AS A FACTOR OF ECONOMIC GROWTH OF SIBERIAN REGIONS}

\author{
V.I. Tatarenko, R. D. Kamalov \\ Novosibirsk State University of Economics and Management (Novosibirsk, Russia)
}

The resource base of Siberia is considered as a strong competitive advantage of Russia. Proper and rational use of the available resources can transform the "raw materials supply" into a driver of significant economic and industrial growth, both in regional economies and in the state. Russia owns more than $30 \%$ of all natural resources in the world. Huge fuel and energy resources are open in almost all economic regions of the Russian Federation, but the major part of them is concentrated in Siberia. Meanwhile, a new step to the economic development of the Siberian regions is in the external economic factor - the "Asian" vector of economic cooperation. Russian-Chinese cooperation can give a new impetus to the social and economic development of Siberian regions.

Keywords: Siberia, industrial resources, economic growth, rationality, subsoil use, innovations, Gazprom, gas, Power of Siberia, China.

C овременное развитие экономики Российской Федерации обусловлено в том числе изменениями, происходящими в политической сфере. Развитие экономики в условиях проводимой Западом «санкционной» политики требует от руководства страны новых подходов и решений. Вместе с тем рост благосостояния страны в целом предлолагает опережающий рост экономического развития ее регионов и, прежде всего, «локомотивных», к числу которых относятся сырьевые регионы Сибири. Опережающий экономический рост этих регионов может быть обусловлен новым вектором - азиатским направлением сотрудничества.

Природно-ресурсный потенциал Сибири - основа промышленного производства. Главные отрасли экономики региона - металлургия, химическая и нефтгазовая промышленность, производство строительных материалов, машиностроение и металлообработка, топливная, легкая, лесная и деревообрабатывающая промышленность.

Одним из ведущих факторов, определяющих перспективы развития Сибири и ее место в россий- 
ской экономике, является огромный ресурсный потенциал этого региона, прежде всего:

- месторождения полезных ископаемых: извлекаемые разведанные запасы нефти в Сибири составляют $77 \%$ российских запасов, природного газа - 85\%, угля - 80\%, меди - 70\%, никеля - 68\%, свинца - 85\%, цинка - 77\%, молибдена - $82 \%$, золота 41\%, металлов платиновой группы - 99\%;

- гидроэнергетические ресурсы - 45\% гидроэлектроэнергетического потенциала России;

- биологические ресурсы: около 9\% мировых запасов;

- древесины (более $41 \%$ российских запасов) $[1]$.

Стоит упоминуть и то, что Сибирь - это крупнейший бассейн углеводорного сырья, находящийся на территории Западно-Сибирской равнины, он распространился на такие регионы, как Томская, Курганская, Тюменская, Новосибирская, Свердловская и Челябинская области, Алтайский и Красноярский края.

В Сибирском регионе открыто огромное количество углеводородов, порядка 500 месторождений. Это около 70\% всех открытых на данный момент месторождений нефти на территории Российской Федерации [2].

Совершенствование нефтегазодобычи за счет открытия и освоения новых месторождений увеличивает для страны возможности роста в этой сфере; а именно увеличение добычи нефтегазопродуктов и выход на лидирующие позиции среди нефтегазодобывающих стран. За сранительно небольшой промежуток времени (порядка 30 лет) в Сибири было добыто около 6 млрд т сырой нефти, или 45\% всей сырьевой добычи нефти в России [3].

Значительное число людей считают, что нефтегазовая отрасль есть аванпост России: как база, которая несет в себе стабильность экомики государства, а также благосостояния населения.

На сегодняшний день современный мир зависим от углеводородов: транспортные средства эксплуатируются за счет нефтепродуктов, из природного газа изготавливаются полимеры, часть медикаментов, даже пластиковые панели, которыми обшивают жилые дома, - результат обработки полезных ископаемых. Все это, без преувеличений, делает газ и нефть самыми полезными и ценными ресурсами не только топливной промышленности, но и остальных отраслей. Поэтому нефтегазовая промышленность в экономике России играет ведущую роль. Газовый и нефтяной комплексы тесно связаны с другими отраслями экономики и производства государства. Товарная структура внутригосударственной и международной торговли полна продуктов переработки газа и нефти.
В структуре экспорта страны сырьевые ресурсы существенно опережают другие его статьи. Коммерческий энергетический баланс во многом зависит от добычи нефти и природного газа. Так, если провести пересчет на нефтяной эквивалент, то на газ и нефть приходится примерно $60 \%$ всемирного потребления источников энергии. В этой связи нефтегазовой промышленности в экономике России отводится ключевая роль.

Экономический рост сибирских регионов в настоящее время в значительной степени обусловлен внешнеэкономическим фактором. Началось и активно развивается сотрудничество России и Китая в нефтегазовом секторе, прежде всего на Востоке России - в Сибирском и Дальневосточном федеральных округах. По замыслу экспертов, оно должно стать основой взаимовыгодного сотрудничества и в других областях. Ярким примером может служить агропромышленный сектор, потенциал которого только в виде поставок в КНР продукции российского сельхозпроизводства китайской стороной оценивается в триллион долларов США.

Взаимовыгодное сотрудничество в различных структурах может успешно развиваться в рамках различных подходов и моделей, которые, в конечном счете, оказывают важнейшее влияние на генерацию и распределение социально-экономических эффектов, связанных с добычей и использованием углеводородного сырья (УВС) как на межгосударственном, так и на региональном уровне. Это придаст сотрудничеству ярко выраженный и стремительный эффект, что быстро улучшит социально-экономическое состояние регионов и страны в целом.

Ключевым элементом развития сотрудничества в газовой сфере является строительство и последующая эксплуатация газопровода «Сила Сибири» и заводов СПГ на Ямале. В 2014 г. Газпром и китайская CNPC подписали договор купли-продажи газа по «восточному» маршруту. Договор заключен сроком на 30 лет и предполагает поставку российского газа в КНР в объеме 38 млрд куб. м в год. В мае 2019 г., согласно официальным пресс-релизам, должны начаться поставки газа в Китай по газопроводу «Сила Сибири» [4].

Расширение деятельности Газпрома на востоке страны создает предпосылки для роста уровня социально-экономического развития регионов Восточной Сибири и Дальнего Востока. В частности, предполагается, что строительство газотранспортных мощностей обеспечит развитие газификации. Кроме того, создание новых центров газодобычи позволит повысить уровень занятости местного населения. Сегодня Газпром организует подготовку специалистов в российских профильных образовательных центрах, стимулирует разработку новых 
учебных программ. На строительстве первой очереди «Силы Сибири» будет задействовано более 11 тыс. специалистов; эксплуатировать газопровод будут около 3 тыс. человек [5].

На Востоке России планируется построить масштабную газовую инфраструктуру, что создаст новые возможности для развития экономики Сибири. При этом следует учитывать, что основные заказы получат предприятия таких отраслей российской экономики, как металлургия, трубная промышленность, машиностроение.

Развитие газодобычи и транспортных мощностей создает предпосылки для строительства новых перерабатывающих производств. Особенностью многих месторождений УВС Восточной Сибири является многокомпонентный состав ресурсов, что определяет необходимость рационального использования значительных объемов попутного нефтяного газа, этана, гелия, газового конденсата.

Освоение и рациональное использование газовых ресурсов Восточной Сибири создает благоприятные предпосылки для осуществления количественного и качественного рывка в развитии российской химической промышленности. Возведение крупных газохимических производств в Восточной Сибири является важнейшей экономической задачей и должно быть подкреплено мерами государственного стимулирования, нацеленного:

- с одной стороны, на поддержку (экономическую, финансовую, политическую) инвестиционных проектов по эффективному использованию ресурсов газа и строительству новых газохимических комплексов;

- с другой стороны, на развитие и стимулирование эффективного внутреннего спроса на разнообразную химическую продукцию.

В какой мере отмеченные выше перспективы по созданию новых мощностей будут реализованы, сейчас прогнозировать довольно сложно. Это зависит от широкого круга факторов, включая динамику цен на УВС, темпы развития экономики, прежде всего в России и Китае, инвестиционные возможности компаний. В любом случае важно, чтобы эти и другие проекты реализовывались не только в интересах крупных корпораций, но и с макси-мальным учетом интересов регионов и населения тех территорий, где они будут размещены. Это подразумевает:

- неукоснительное выполнение экологических требований;

- привлечение местной рабочей силы, повышение уровня ее квалификации, развитие человеческого капитала;
- не только увеличение экспорта продукции, но и использование значительной части продукции для местных нужд;

- максимально возможное привлечение местных поставщиков и подрядчиков.

Одним из ключевых факторов с точки зрения формирования социально-экономических эффектов, связанных с добычей УВС на территории России, является локализация объектов (первичной и глубокой) его переработки. Конечно же, генерация и распределение выгод зависит от целого ряда других важных факторов и условий, среди которых следует особо отметить:

- участие в строительстве нефтегазовых объектов (рабочая сила, технологии, оборудование, инвестиции). Возможно, как участие китайских компаний в создании новых мощнотей на территории России, так и участие российской стороны в строительстве новых объектов в Китае;

- локализация мест основного потребления продукции переработки (например, в случае развития глубокой переработки УВС важно, какая часть нефтехимической продукции будет экспортироваться, а какая потребляться в России);

- долевое участие корпораций в капитале компаний, занимающихся добычей и переработкой УВС.

Тематика изучения проблем и особенностей развития ресурсных регионов далеко не нова и отличается как значительным числом работ, так и целым рядом имен выдающихся исследователей, получивших интересные научные и в то же время практически значимые результаты. Несмотря на это, проблемы развития экономики и социальной сферы ресурсных регионов по-прежнему находятся в фокусе исследователей самых различных специальностей и направлений в разных странах (независимо от того, на сколько и в какой степени экономика и социальная сфера той или иной страны «подвержены» влиянию ресурсного фактора).

С одной стороны, это связано с глобальными процессами экономического развития - все большее число стран, ранее имевших «классическую» ресурсную экономику, переходит в категорию развитых; с другой стороны, в самом сырьевом секторе происходят фундаментальные (можно сказать «тектонические» сдвиги) и кардинальные изменения (в силу существенного возрастания роли экономики знаний и в целом интеллектуальной составляющей) в процессах освоения и использования природных ресурсов. Ряд развитых стран возвращается в число «ресурсозависимых», однако и это явление, и его особенности имеют совсем иную природу и отличаются значительным возрастани- 
ем роли и места экономики знаний. Итак, характеризуя складывающуюся в российско-китайских отношениях обстановку, можно с уверенностью утверждать, что претворение в жизнь и реализация намеченных планов и проектов этого сотруд- ничества послужит ярко выраженным драйвером социально-экономического развития сырьевых регионов Сибири и позволит создать предпосылки опережающего развития экономики Российской Федерации.

\section{БИБЛИОГРАФИЧЕСКИЙ СПИСОК}

1. Мир после кризиса. Глобальные тенденции - 2025: меняющийся мир. Доклад Национального разведывательного совета США. М. : Европа, 2009. 188 с.

2. Россия: восточный вектор. Предложения к стратегии развития Сибири и Дальнего Востока. Аналитический доклад / под ред. В. С. Ефимова, В. А. Крюкова. Красноярск : Сиб. федерал. ун-т, 2014. 92 с.

3. Экономическая и социальная география Сибири : учебно-методический комплекс / Н. В. Ионова ; Новосиб. гос. пед. ун-т, Ин-т открытого дистанционного образования. Новосибирск : НГПУ, 2011. [Электронный ресурс]. URL: http://lib.nspu.ru/umk/c59fa3ebaffb1c7a/

4. Официальный сайт AO «Газпром». Проект «Сила Сибири». [Электронный ресурc]. URL: http://www. gazprom.ru/projects/power-of-siberia/

5. Ресурсные регионы России в «новой реальности» / под ред. акад. В. В. Кулешова Новосибирск : Изд-во ИЭОПП СО РАН, 2017. 308 с.

\section{REFERENCES}

1. The world after the crisis. Global Trends - 2025: A Changing World. Report of the National Intelligence Council (2009). Moscow, 188 (in Russian).

2. Russia: Eastern vector. Proposals for development strategies for Siberia and the Far East. Analytical report (2014). Ed. V. S. Efimov, V. A. Kryukov. Krasnoyarsk, 92 (in Russian).

3. Ionova N.V. (2011) Economic and social geography of Siberia: educational and methodical complex. Novosibirsk. URL: http://lib.nspu.ru/umk/c59fa3ebaffb1c7a/ (in Russian).

4. The official website of "Gazprom". The "Power of Siberia" project. URL: http://www.gazprom.ru/projects/ power-of-siberia/ (in Russian)

5. Regional resources in the "new reality" (2017). Ed. V. V. Kuleshov. Novosibirsk, 308 (in Russian).

Поступила в редакцию: 09 ноября 2018 г. Принята к печати: 14 января 2019 г. 